\title{
LUIZ MOTT
}

\section{A rearoluş̃̃o}

homoxrexutal:

\section{o poder}

\section{de um milro}

LUIZ MOTT é professor

do Departamento de

Antropologia da UFBa e

presidente do Grupo Gay

da Bahia. 


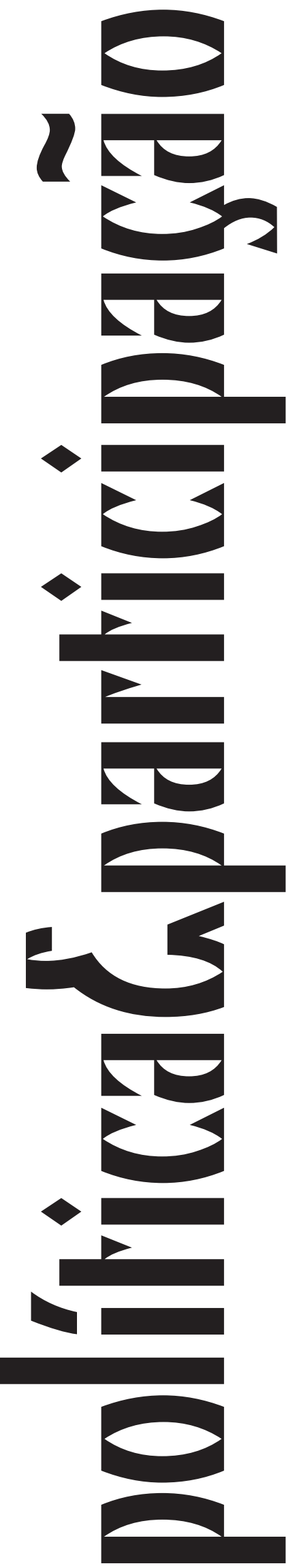
"Sodoma quer dizer traição. Gomorra, rebelião"
(Frei Felipe Moreira, 1645).

\author{
"O buraco do meu cu é revolucionário!" \\ (Guy Hocquenghem, 1980).
}

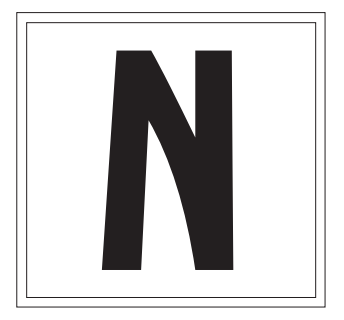

os últimos quatro mil anos, nas diferentes civilizaçôes que serviram de matriz à cultura ocidental, a homossexualidade foi rotulada por diversos nomes atrozes que refletem o alto grau de reprovação associado a esta performance erótica: abominação; crime contra a natureza; pecado nefando; vício dos bugres; abominável pecado de sodomia; velhacaria; descaração; desvio; doença; viadagem; frescura, etc. (1). E os homossexuais - mais os do sexo masculino do que as lésbicas - foram condenados a diferentes penas de morte: apedrejados, segundo a Lei Judaica; decapitados, por ordem de Constantino em 342 d. C.; enforcados, afogados ou queimados nas fogueiras da Inquisição, durante a Idade Média e até os tempos modernos; despedaçados na boca de um canhão, como se registrou no Maranhão colonial (2); queimados pelos nazistas nos campos de concentração (3). Hoje, no Brasil, a cada dois dias, um gay, travesti, transexual ou lésbica é brutalmente assassinado, vítima da homofobia - o ódio à homossexualidade (4), fazendo de nosso país o campeão mundial de crimes homofóbicos. Por todo o país, pais e mães proclamam sem pejo: "prefiro um filho ladrão do que homossexual" ou "antes uma filha prostituta do que lésbica" (5).

O objetivo deste ensaio é reconstituir a gênese e o significado da homofobia em nossa sociedade: através da etno-história mostrarei que nossa intolerância anti-homos-

Wayne Dynes (ed.), Encyclopedia of Homosexuality, New York, Garland, 1990: Homolexis: a Historical and Cultural Lexicon of Homosexuality, New York, Gai Saber Monograph, 1985.

2 Luiz Mott, A Inquisição no Maranhão, São Luís, Editora da Universidade Federal do Maranhão, 1994.

3 George Haggerty (ed.), Gay Histories and Cultures, New York, Garland Publishing Inco, 2000.

4 LuizMotte Marcelo Cerqueira Causa Mortis: Homofobia Salvador, Editora Grupo Gay da Bahia, 2001.

5 Luiz Mott, Violação dos Direitos Humanos e Assassinato de Homossexuais no Brasil, Salvador, Editora Grupo Gay da Bahia, 2000 
sexual tem suas raízes na tradição judaicocristã, que desde cedo percebeu o caráter ameaçador, político e revolucionário da homossexualidade, daí transformar o sexo e amor entre pessoas do mesmo gênero em crime abominável e o mais detestável de todos os pecados. Hoje, quando se ouve de norte a sul do Brasil esta sentença de morte: "Veado tem mais é que morrer!", inconscientemente, está-se repetindo um veredicto que foi atribuído à própria vontade divina, imaginando-se assim evitar, através da repressão e aniquilação dos praticantes do "amor que não ousa dizer o nome", a destruição da própria humanidade.

Discutirei igualmente como a homofobia judaico-cristã tornou-se ainda mais virulenta em nosso país, devido ao escravismo colonial, na medida em que os "efeminados" eram vistos e tratados como perigosa ameaça à hegemonia do macho branco e à continuidade do projeto colonizador do Novo Mundo. Demonstrarei que a homossexualidade carrega na sua própria essência aspectos explosivos, representando uma verdadeira revolução dos costumes, na medida em que questiona, ameaça e pode destruir os mesmos alicerces em que se escoram a moral e a sexualidade na cultura tradicional do Ocidente. Uma revolução positiva, convém não se esquecer, pois nos obriga a repensar diversos axiomas fundantes de nossa cultura hodierna, que de forma irrefletida e perversa persistem em nossa ideologia e modus vivendi, fazendo da terra, e de nosso Brasil, não um paraíso terreal, mas um vale de lágrimas, e da sexualidade e das relações de gênero, a fonte de tanta violência, tragédia e morte.

6 John Boswell, Same Sex Unions in Pre-Modern Europe, New York, Villard Books, 1994 Christine Downing, Myths and Mysteries of Same-Sex Love New York, Continuum, 1996

7 Salomon Reinach, Orpheus: Histoire Générale des Religions, Paris, Alcide Picard, Editeur, 1909; Jack Miles, Deus: uma Biografia, São Paulo, Companhia das Letras, 1997.

8 Bíblia Sagrada, São Paulo Editora Ave Maria, 1985 Gênesis, 12:1;13:14; 15:18 que permanece ainda hoje como o maior tabu do mundo moderno: a homossexualidade (6). Sua gênese teve lugar por volta de quatro mil anos passados, na Caldéia, quando um velho pastor, Abraão, divulga junto a sua parentela e vizinhança certas revelações que assegurava ter recebido do próprio Deus, escolhendo-o como fundador de um povo predestinado. Elabora-se então, nesse momento, um projeto civilizatório que vai se tornar o mito fundador não só do povo judeu, como da própria história genealógica das três principais religiões do mundo moderno: judaísmo, cristianismoe islamismo.

Segundo se pode ler no primeirolivro da Bíblia, o Gênesis, Abrão teria nascido em Ur, na Caldéia, casado com Sara, que era estéril. Conjecturam os historiadores e exegetas que, por volta do ano 1800 a. C., toda sua família e agregados partem em direção à terra de Canaã, estabelecendo-se em Harã, onde seu progenitor Taré falece aos 205 anos de idade. É aí que tem início o diálogo de Javé com Abrão e a origem do mito que serviu de base e justificativa não só à posterior condenação do homoerotismo, mas da violenta sexofobia que vai caracterizar e distinguir a cultura sexual judaica da sexualidade dos povos circundantes (7).

Eis a versão original do mito:

“O Senhor disse a Abrão: Deixa tua terra, tua família e a casa de teu pai e vai para a terra que eu te mostrar. Farei de ti uma grande nação. Eu te abençoarei e exaltarei o teu nome, e tu serás uma fonte de bênção. Todas as famílias da terra serão benditas em ti... Tornarei tua posteridade tão numerosa como o pó da terra... Levanta os olhos para os céus e conta as estrelas se és capaz... Pois assim será a tua descendência... Eu dou esta terra aos teus descendentes, desde a torrente do Egito até o grande rio Eufrates..." (8).

Passam-se anos, e Abrão e Sara continuavam sem descendentes consangüíneos. Ao completar 99 anos, Javé aparece-lhe, ratificando a promessa: “Quero fazer uma aliança contigo e multiplicarei ao infinito a 
tua descendência... De agora em diante não te chamarás mais Abrão, e sim Abraão, que quer dizer pai de uma multidão de povos..."

É sintomático que exatamente após essa aliança estabelecida entre Javé e Abraão, pouco antes de Sara engravidar, são destruídas as cidades de Sodoma e Gomorra, o principal símbolo da homossexualidade no mundo antigo. Motivo: "o seu pecado era muito grande!” (9). Logo em seguida nasce Isac, a prova de que para Deus nada é impossível, concretizando-se assim a primeira profecia. Adulto, Isac casa-se com Rebeca, dando origem ao povo hebreu.

Segundo ensina a etnodemografia, podemos dividir as diferentes sociedades humanas em dois grandes complexos no que tange a seu projeto civilizatório: de um lado as culturas pró-natalistas, que estimulam a procriação, aspiram à longevidade máxima, reprimem e diabolizam o sexo nãoreprodutivo, canalizando toda a energia sexual para a multiplicação máxima da espécie; do outro, as sociedades antinatalistas, que limitam os nascimentos, estimulam práticas anticoncepcionais, abortíferas ou mesmo o infanticídio, onde o sexo visa primordialmente o prazer e não a reprodução (10).

Nós, os povos espiritualmente descendentes de Abraão, judeus, cristãos e muçulmanos, somos herdeiros típicos da ideologia demográfica pró-natalista, onde a religião e a moral ensinam que o sexo se destina precipuamente à reprodução, tendo como base a ordem do Divino do Criador: "crescei e multiplicai-vos".

Rodeados por nações antigas, superpopulosas e poderosas - assírios, babilônicos, caldeus, hititas, egípcios -, os hebreus, este pequenino bando de pastores nômades, não tinham outro caminho para atingir seu ambicioso projeto civilizatório: fazer filho, fazer muitos filhos, engravidando ao máximo suas mulheres e escravas, a fim de cumprir a promessa feita por Javé ao patriarca Abraão: "Multiplicarei a tua posteridade como as estrelas do céu e as areias do mar!". Destarte, o exercício da sexualidade passou a ter apenas um objetivo: povoar de estrelas-humanas as areias do deserto, pro- criar novos guerreiros capazes de enfrentar os violentos inimigos, esses, sempre desejosos de curvar o orgulho daquela pequenina tribo de pastores endogâmicos, que propalava ser o único povo escolhido pelo verdadeiro Deus, Javé, o Deus dos Exércitos. E que tratava os povos vizinhos como gentios, e suas divindades, como falsos deuses.

Cada gota de esperma desperdiçado passou a constituir verdadeiro crime de lesanacionalidade, pois todo sêmen deveria ser depositado no único receptáculo capaz de reproduzir um novo ser humano: o vaso natural da mulher. Daí o Levítico condenar à pena de morte os que praticassem a masturbação, o coito interrompido ("onanismo"), o bestialismo e a homossexualidade. "Não te deitarás com um homem como se fosse mulher: isto é uma abominação. Não terás comércio com um animal, para não te contaminares com ele. Uma mulher não se prostituirá a um animal, isto é uma abominação" (11).

A relação homoerótica masculina foi mais perseguida do que os demais atos nãoreprodutivos por uma simples lógica aritmética: são dois "semeadores" que desperdiçam a semente vital, diferentemente de quando um homem se masturba ou mantém relação com algum animal, ocorrendo a perda de apenas um produtor da semente vital. É dentro desta lógica, visando a maximização do aproveitamento do esperma, que o Antigo Testamento praticamente ignorou a existência do lesbianismo dentro do povo judeu. A relação sexual entre duas mulheres não representava a menor ameaça ao projeto super-reprodutivo tribal, posto que nessa sociedade machista e patriarcal não se levava em conta o interesse ou desejo sexual das fêmeas, mas a vontade e o prazer do macho e seu orgulho em demonstrar, com farta prole, sua potência e poder. Mesmo lésbicas, as filhas de Eva eram obrigadas a se casar e oferecer seu vaso natural à procriação.

Um outro elemento ideológico, também de inspiração mitológica, reforçou ainda mais o direcionamento da libido exclusivamente para a reprodução, e a conseqüen-

\footnotetext{
9 Gênesis, 18:20

10 Dennis Werner, On the So cietal Acceptance or Rejectio of Male Homosexuality, M. A Thesis, Junter College, 1975; "ACross-cultural Perspective on Teory and Research on Male Homosexuality", in Journal of Homosexuality vol. $4(4)$ Summer/1979, pp. 345-62

11 Levífico, 18:22
} 
te criminalização dos atos sexuais nãoprocriativos, notadamente da performance que mais desperdiçava o sêmen vital, a sodomia homossexual. Trata-se do mito do nascimento do Messias: o enviado de Deus, nascido de uma virgem, encarregado por Javé de instaurar a utopia a que todos aspiravam, transformando as espadas em arados, os rios em correntes de leite e mel, onde os leões e cordeiros viveriam para sempre em paz (12). Esse paradisíaco reino da abundância e da concórdia dependia apenas de um simples ato para tornar-se realidade: o nascimento do messias através de uma cópula heterossexual. De modo que, ao se desperdiçar o sêmen, não era apenas um novo pastor/guerreiro que deixava de nascer: o próprio Messias estava sendo impedido de trazer a felicidade ao povo eleito, um crime de lesa-divindade.

É este, portanto, o mito fundador que inspirou o projeto civilizatório e expansionismo demográfico dos povos descendentes de Abraão, justificando a brutal condenação ao homoerotismo masculino e, em decorrência, a própria destruição dos principais nichos simbólicos desse abominável desperdício do sêmen, as cidades de Sodoma e Gomorra e suas cinco sucursais diabólicas, a Pentápolis (13).

\section{RAÍZES DA HOMOFOBIA: 0 MEDO DA REVOLUC̦̃̃O HOMOSSEXUAL}

Para nossos ancestrais judeus e, posteriormente, em toda a cristandade, o preconceito homofóbico tinha como justifica-

12 Isaías 7: 13; 65:25; Joel, 4:10

13 Gênesis, 18

14 Confissões da Bahia, 1591 1592, Primeira Visitação do Santo Ofício às Partes do Brasil, Rio de Janeiro, F. Briguiet, 1935, pp. 46-47.

15 Luiz Mott, "Pedofilia e Pederastia no Brasil Antigo", in Mary del Priore led.l, História da Criança no Brasil, São Paulo, Contexto, 1991

16 Lujo Basserman, História da Prositivição. Uma Interpretação Cultural, Rio de Janeiro, Civilização Brasileira, 1968 naturalidade da divisão sexual do trabalho e dos papéis de gênero.

Grande parte da condenação à cópula anal heterossexual, divulgada nos manuscritos de comentários rabínicos, nos compêndios de teologia moral e manuais de confessores, explica-se por uma simples razão: o perigo da confusão dos vasos.

De acordo com a terminologia anatômica dos tratados de moral cristã e dos regimentos do Santo Ofício da Inquisição, o corpo humano comporta dois vasos: as mulheres possuem o vaso natural ou dianteiro, onde o membro viril derrama a semente de homem; mulheres e homens possuem o vaso traseiro, também referido nos séculos passados como vaso prepóstero, traseira, via posterior ou via do curso. Em alguns processos inquisitoriais, inclusive no Brasil, percebe-se um temor obsessivo, por parte dos amantes mais descontrolados, de terem inadvertida, ou maliciosamente, confundido os vasos, copulando "à moda de Sodoma" em vez de usar o vaso dianteiro. Na Bahia, em 1591, o cônego Jácome de Queiroz, 46 anos, morador em Itapoã, confessou perante o Visitador do Santo Ofício que "numa noite levou à sua casa uma moça mameluca de 6 ou 7 anos, escrava, que andava vendendo peixe pela rua, e depois de cear e se encher de vinho, cuidando que corrompia a dita moça pelo vaso natural, a penetrou pelo vaso traseiro e nele teve penetração... E outra vez, querendo corromper outra moça, Esperança, sua escrava de 7 anos, a penetrou também pelo traseiro" (14). O remorso desse cônego pedófilo e seu crime não eram a infantilidade e pureza dessas duas meninas pré-púberes, mas o fato de ter praticado, mesmo que afetado pelo vinho, "o abominável crime de sodomia, o mais torpe, sujo e desonesto pecado"(15).

Os moralistas e donos de poder sempre condenaram e reprimiram a tentação de se usar o vaso traseiro, como via ou locus do prazer, como solução para evitar a gravidez ou até, no caso do sexo com mulheres públicas, como alternativa menos perigosa de contágio das doenças do mundo ("mal gálico", entre outras) (16). Isto no que se 
refere ao trato erótico heterossexual, embora a maior repressão incidisse exatamente contra os adeptos da cópula anal entre machos - tanto que não chega a $5 \%$ o número de prisões de mulheres e homens envolvidos em relações anais, se comparados com os copuladores homoeróticos aplicando-se pena máxima da fogueira registrando-se tão-somente aos parceiros do mesmo sexo (17).

Repetimos: a sodomia homossexual sempre foi mais reprimida do que o sexo anal heterossexual por duas razões: por serem dois os indivíduos a desperdiçarem o esperma, e por ameaçarem não apenas o projeto demográfico expansionista, primeiro dos judeus, depois da cristandade e do Islão, mas por ostentarem os homens sodomitas um estilo de vida incompatível com os pressupostos fundantes da família patriarcal de tradição abraâmica (18).

Ensina a antropóloga inglesa Mary Douglas, ao interpretar as abominações do Levítico, que o nosso Deus, por ser puro espírito, não tolera a mistura: "Vós sereis santos porque eu sou santo', disse o Senhor. A santidade é exemplificada pela integridade. A santidade requer que os indivíduos se conformem à classe à qual pertencem. E a santidade requer que diferentes classes de coisas não se confundam Outro conjunto de preceitos aperfeiçoa esta idéia. A santidade significa manter distintas as categorias da criação. Ser santo é ser total, ser uno. A santidade é unidade, integridade, perfeição dos indivíduos e das espécies"(19).

Não é só o Levítico que rejeita a mistura: também no Apocalipse, João, "o discípulo que Jesus amava”, reforça o mesmo dogma: "Por que não és frio, nem quente, e sim morno, eu te vomitarei!" (20). Na classificação bíblica dos animais, dos atos e condutas puras e impuras, impera irredutível maniqueísmo: a indistinção das categorias representa mais do que uma aberração, é uma abominação detestável, um horror. Por exemplo, "um homem dormir com outro homem como se fosse mulher" é abominável pois contradiz a ordem natural prevista pelo Criador, ao dividir os seres vivos em machos e fêmeas. Ou como diversas vezes me disseram apologeticamente alguns protestantes mais simplórios: "se Deus tivesse planejado o homossexualismo, teria criado Adão e Ivo e não Adão e Eva...". Para estes, repito o douto comentário do Filho de Deus: "Bem-aventurados os pobres de espírito...”.

Como outros “desvios" sexuais, na ótica veterotestamentária, o amor entre dois homens também foi considerado por Deus como abominação gravíssima, punível com a morte por apedrejamento, posto que o macho foi criado exclusivamente para depositar seu esperma no vaso natural da fêmea. Os sodomitas, ao contrário, além de usarem um vaso impuro, correm o risco de misturar matérias inconciliáveis, a cândida semente do homem com o vil excremento fecal.

Num mundo de extrema violência como era o cenário bíblico na Antigüidade - consulte-se o Livro de Josué como ilustraçãoaquele bando de pastores nômades desenvolveu códigos de sociabilidade e papéis sociais fortemente hierarquizados e rudes, pois a segurança e a sobrevivência das mulheres, crianças, dos anciãos e rebanho, dependiam vitalmente da força física individual e coletiva dos machos adultos. Tornou-se crucial o fortalecimento e dureza do papel de gênero masculino, a rígida divisão sexual, de um lado o mundo dos superhomens, ligado às armas, à guerra, ao enfrentamento do mundo hostil; do outro, o mundo feminino, submisso, doméstico, voltado para a prole, recluso. Misoginia institucionalizada que se refletia inclusive no espaço marginal ocupado pelas mulheres no culto javédico, devendo ficar confinadas nos corredores laterais fora do salão principal da sinagoga, postura, aliás, que o principal teórico do cristianismo, o exfariseu Paulo, reforçou ao determinar que as filhas de Eva jamais usassem a palavra em público (21).

Como muitos outros povos, também os descendentes de Abraão herdaram forte tradição falocrática: o macho tem no falo a origem e legitimação do seu poder. A mulher vale, primeiro, pelo hímen intacto;
17 Luiz Mott, "Pagode Português: a Subcultura Gay em Portuga nos Tempos da Inquisição", in Ciência e Cultura, vol. 40 fev./1980, pp. 120-39 "Justitia et Misericordia: Inquisição Portuguesa e a Re pressão ao Nefando Pecado de Sodomia" in Anita Novinsky et al. (eds.l, Inquisição: Ensaios sobreMentalidade Heresias e Arte São Paulo, Edusp/Expressão Cultura, 1992, pp. 703-38.

18 R. Trumbach, "Sodomite Sub cultures, Sodomitical Roles and the Gender Revolution of the XVIlth Century: The Recen Historiography" in EighteenthCentury Life, no 1985 po. 109 21

19 Mary Douglas, Pureza e Peri go, São Paulo, Perspectiva 1976, p. 70

20 Apocalipse, $3: 16$

21 / Coríntios, 14:34 
22 Afrânio Peixoto, Sexologia Fo rense, Rio de Janeiro, Guanabara, 1934. Este autor baian foi quem mais divulgou a ex pressão "himenolatria", entatizando sua importância na construção da moral-sexual brasile ra naquela época.

23 J. G. Peristiany, Honra e Vergonha: Valores das Sociedades Mediterrânicas, Lisboa, Fundacão Calouste Gulbenkian 1988

24 Levítico, 2:, 10; Deuteronômio $22: 2 ; 13: 21$

25 Vern L. Bullough, Sexual Vari ance in Society and History, Chicago, The Chicago University Press, 1976.

26 Deuteronômio, 22:5.

27 Vern L. Bullough, Science in Bedroom. A History of Sex Research, New York, Basic Books, 1994

28E. M. Yamaguchi, "Cultic Prostitution: a Case Study in Cultural Diffusion", in Orientand Occident, Kevelear, Verlag Butzon \& Becker, 1973, pp. 213-22; T. Jonathan Horner Jonathan Loved David: Homo sexuality in Biblical Times, Philadelphia, Westminster 1978 depois de deflorada por seu legítimo marido e senhor, vale pela fertilidade de suas entranhas e fidelidade a seu esposo. Falocracia e himenolatria (22) tornaram-se valores sustentados pelas noções de honra e vergonha (23). O levirato - aquele antigo costume judaico de a viúva ser apropriada pelo cunhado sobrevivente - ratifica os direitos do macho sobre todas as mulheres do clã. Mulher de meu irmão não será usada por macho estranho: a adúltera e a falsa virgem eram igualmente condenadas à pena de morte por apedrejamento (24).

Nesse contexto de rígida divisão sexual e superioridade masculina, o travestismo e inversão de gênero, fenômenos observados em maior ou menor grau na maioria das sociedades antigas e contemporâneas (25), eram repelidos como impertinente desafio à ordem divina e, portanto, gravíssima abominação: a tentação de alguns homens de vestir-se e viver como se mulheres fossem era severamente punida. "A mulher não se vestirá de homem, nem o homem se vestirá de mulher: aquele que o fizer, será abominável diante do Senhor teu Deus!"'(26).

Para o judaísmo, a unissexualidade é sempre uma abominação, porém em grau diferente de gravidade moral: a mulher que se traveste representa uma invasão indébita no universo próprio dos homens, uma usurpação e ameaça à hegemonia do macho. Desvio mais fácil de ser controlado e com consequiências menos deletérias. $\mathrm{O}$ travestismo no homem representava, e continua representando, ameaça muito maior, pois é visto como rebaixamento do sexo forte, desonra e sobretudo abdicação imperdoável do direito natural e divino à hegemonia do sexo forte. Um homem vestido de mulher rebaixa-se à condição de sexo frágil, segundo sexo - ou melhor, terceiro sexo, para utilizar a terminologia muito em voga nos meados do século XIX (27).

Assim sendo, o desejo da androginia ou da unissexualidade, mais do que uma mera desobediência estética, era visto como perigosa ameaça à separação e tradicional antagonismo dos papéis de macho e fêmea, não apenas no vestir e agir, como nas fun- ções vitais de manutenção dessa sociedade, sobretudo no tocante à subsistência material e à segurança. Daí Javé abominar quem ousasse vestir-se com roupa do sexo oposto. Mulheres masculinizadas, guerreiras, foram até honradas com as bênçãos divinas, em certos momentos de crise da história de Israel. Homem efeminado, ou vestido de mulher, abominação! Os opostos têm de ser mantidos como garantia de que os fortes continuarão defendendo e mandando nos fracos.

Acresce-se um crucial fator de afirmação religiosa na oposição de nossos ancestrais à homossexualidade masculina e ao travestismo: a condenação da idolatria dos pagãos, cujos rituais incluíam a presença de prostitutos sagrados, sacerdotes e deuses que tinham no homoerotismo a realização de nobres ideais de piedade e virtude. Segundo ensinam as modernas pesquisas de exegese bíblica e história comparada das religiões, diversos povos vizinhos dos judeus praticavam a kadeshah, a prostituição sagrada, cabendo aos prostitutos homossexuais, os kadesh, importante papel nos rituais de hierodulia. Assim, ao condenar a relação sexual entre homens, além dos preconceitos machistas acima apontados, há de se levar em conta na homofobia bíblica a intenção de negar e abominar a tentação da idolatria gentílica, que tinha no homoerotismo uma forma piedosa de culto à divindade (28).

Mais que o travestismo, o maior perigo representado pelo homoerotismo sempre foi o questionamento da naturalidade dos papéis de gênero atribuídos aos dois sexos. Um homem que abdica do privilégio de ser guerreiro, ou mesmo de servir como sacerdote no altar do Deus dos Exércitos, optando por tarefas e ocupações inferiores identificadas com o universo feminino, provoca uma crise estrutural de proporções imprevisíveis, pois tal novidade poderia se tornar prevalente, ameaçando gravemente a perpetuidade deste povo e segurança nacional. Muitos gays, em incontáveis sociedades, distinguem-se dos demais machos exatamente por esse hibridismo comportamental e ocupacional, quando não pela inversão total de 


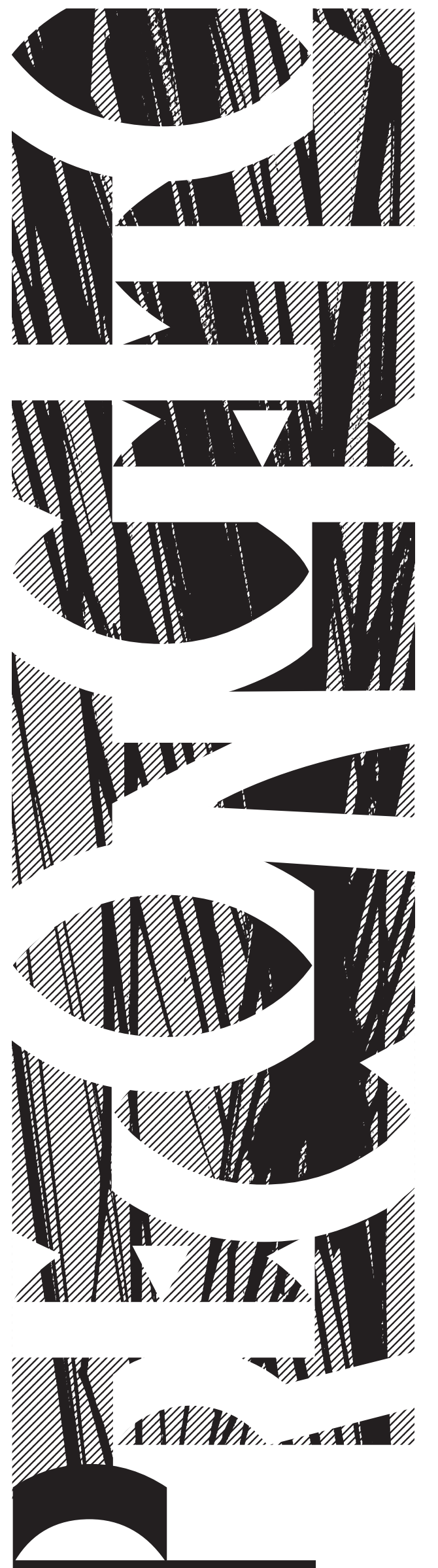

papéis e tarefas socioeconômicas, novidade performática que põe em risco a tradicional divisão sexual do trabalho.

Outro grave perigo representado pelos sodomitas seria a invasão do homoerotismo nas hostes guerreiras e acampamentos de pastores. Em sociedades rigidamente divididas pelas fronteiras do sexo, onde homens passavam boa parte do dia isolados entre si, prolongando-se ainda mais tal apartação nos períodos de guerra, a permanência dessas comunidades unissexuais torna quase incontrolável o pipocar de interações homoeróticas. Diversos são os exemplos de povos guerreiros, como os gregos, os índios caduveus, entre outros, cujas culturas, fortemente inspiradas pela ideologia antinatalista, permitiam e facilitavam a constituição de parcerias homossexuais nas campanhas militares e academias, predominando nalgumas formações históricas, como entre nossos ameríndios, a formação de "casais", onde uma das partes assumia papel andrógino ou tipicamente feminino (29), noutras, como entre os dóricos, os dois parceiros mantinham postura viril, numa relação que a antropologia chamaria de reciprocidade equilibrada (30).

\section{NAS TREVAS DO PRECONCEITO}

Um traço significativo chama a atenção no estudo da homossexualidade ocidental: a inexistência de comprovação de que a lei de Moisés, condenando à morte por apedrejamento "o homem que dormir com outro homem como se fosse mulher", tenha efetivamente sido cumprida. Nas escrituras sagradas não há referência a nenhuma execução, e durante os muitos séculos que os judeus estiveram submetidos a diferentes cativeiros, depois que o Reino da Judéia perdeu sua independência, não dispunham de autonomia legal para aplicar a pena de morte de acordo com as prescrições do Levítico (31). Curioso que, em vez de cenas de apedrejamento, o Antigo Testamento revela quando menos "um caso de amor descaradamente homossexual: a ami-

29 Luiz Mott, "Ethno-histoire de l'Homossexualité en Amérique Latine", in François Crouzet (ed.), Pour l'Histoire du Brésil, Paris, L'Harmattan, 2000, pp. 285-303.

30 K. J. Dover, A Homossexualidade na Grécia Antiga, São Paulo, Nova Alexandria 1994

31 Wayne Dynes, op. cit., "PostBiblical Judaism", p. 642. 
zade imorredoura entre Davi e Jônatas". Apesar de alguns biblistas insistirem que se tratava de um amor meramente espiritual, a que rotulam de ágape, cada vez mais, os exegetas entendem que se tratava mesmo do amor inspirado em eros, "o mesmo tipo de relação existente entre Aquiles e Pátroclo na Ilíada, à de Gilgamesh e Enquidu na Epopéia de Gilgamesh, e à de Alexandre Magno e Hefestion”. Afirmação tão ousada não é de um militante gay, mas do sacerdote Tom Horner, doutor em Literatura Religiosa pela Universidade de Columbia, autor de O Sexo na Bíblia (32). As palavras de Davi, quando da morte de seu parceiro, não deixam dúvidas dessa paixão homoerótica: “Meu coração chora por tua causa, meu irmão Jônatas; quão agradável me eras: mais delicioso me era o teu amor do que o amor das mulheres" (33). Segundo analisa o mesmo estudioso, "tais homens não eram de forma alguma efeminados: eram guerreiros amigos, essencialmente bissexuais".

Duas correntes de historiadores disputam entre si a melhor interpretação da evolução da intolerância anti-homossexual na tradição judaico-cristã. A explicação tradicional, inspirada nos próprios textos bíblicos e no historiador Josephus, contemporâneo de Cristo, defende que desde os tempos do Levítico, sem solução de continuidade, predominou a intolerância máxima contra os "sodomitas", assim como em relação às demais expressões sexuais que não fossem a conjugalidade monogâmica.

A outra interpretação, com base nas eruditas e inéditas pesquisas do dr. John Boswell, em seu clássico Christianity, Social Tolerance and Homosexuality, defende que o primeiro milênio do cristianismo foi muito mais tolerante à homossexualidade do que vulgarmente se imagina: padres, reis e nobres, até santos, foram publicamente reconhecidos como amantes do mesmo sexo; poesia e prosa, de inspiração cortesã ou mística, cantam o amor pelo amigo (34); a própria expressão gay, popularizada nos meados do século XX nos países de língua inglesa, e depois universalmente, como sinônimo de homossexu- al, já seria utilizada desde o século XIII, na língua catalã-provençal, como equivalente de "rapaz alegre". Ainda nesta linha, pretendem os seguidores desta corrente interpretativa que a própria associação da destruição de Sodoma e Gomorra, e a conseqüente identificação da "sodomia" à cópula anal, foi uma construção historicamente datada, a partir do primeiro século da era cristã, com nítida influência do estoicismo, tanto que uma dezena de profetas e o próprio Cristo atribuem a destruição dessas duas cidades não à imoralidade sexual, muito menos ao homoerotismo, mas a outros pecados considerados na época merecedores de severa punição divina, como a falta de hospitalidade e a impiedade (35). Portanto, foi com base numa interpretação errônea, e em contradição aos principais escritores bíblicos, inclusive aos comentários do próprio Filho de Deus, que alguns padres da Igreja passaram a identificar o pecado de Sodoma com a homossexualidade, elaborando argumentos teológicos que serviram de justificativa para a punição de seus praticantes (36).

Segundo odr. Boswell, teria sidosomente a partir do século XIII que a Europa presencia o desenvolvimento generalizado de dois ódios que marcarão profundamente nosso mundo no último milênio: a homofobia e o anti-semitismo. No caso daintolerância antihomossexual, é sobretudo graças ao dominicano Santo Tomás de Aquino (12251274) que a sodomia passa a ser oficialmente considerada peccatum contra naturam, $\mathrm{e}$ os homossexuais confirmados como provocadores de castigos divinos e toda sorte de calamidades à cristandade:

"Sobre todos os pecados, bem parece ser o mais torpe, sujo e desonesto o pecado de Sodomia, e nãoé achado um outro tão aborrecido ante a Deus e o mundo, pois por ele não somente é feita ofensa ao Criador da natureza, que é Deus, mais ainda se pode dizer, que toda a natureza criada, assim celestial como humana, é grandemente ofendida: somente falando os homens neste pecado, sem outro ato algum, tão grande é o seu aborrecimento que o ar não o pode 
sofrer, mas naturalmente fica corrompido e perde sua natural virtude. Por este pecado lançou Deus o dilúvio sobre a terra e por este pecado soverteu as cidades de Sodoma e Gomorra; por este pecado foi destruída a Ordem dos Templários por toda a Cristandade em um dia. Portanto mandamos que todo homem que tal pecado fizer, por qualquer guisa que ser possa, seja queimado e feito pelo fogo em pó, por tal que já nunca de seu e corpo e sepultura possa ser ouvida memória" (37).

Como se constata, diversas tragédias da história humana foram atribuídas aos amantes do mesmo sexo: o dilúvio universal, a destruição de Sodoma, Gomorra e das cinco cidades circundantes. O principal teólogo franciscano medieval, São Boaventura (1221-1274), defendia que a razão da demora de Jesus Cristo se encarnar, desde a remota promessa feita por Javé a Abraão, se devia ao fato de a terra estar sobremaneira infestada de sodomitas, e que na noite de Natal morreram multidões dessas imundas criaturas (38). Além de ter causado o desmantelamento da famigerada Ordem dos Templários (1123-1312), atribui-se aos homossexuais a derrocada de dois grandes impérios antigos: a queda do Império Romano e a perda da Andaluzia pelos mouros. Razões abundavam, no imaginário popular, para se temer o amor homoerótico! (39).

Tomarei, como fio condutor para interpretar o recrudescimento da intolerância anti-homossexual na baixa Idade Média, três hipóteses, todas elas direta ou indiretamente vinculadas ao temor do componente perturbador e revolucionário associado à homossexualidade, a saber: tentativa de expurgar a expansão do homoerotismo no clero e nas ordens religiosas; reação à depopulação da Europa decorrente da peste negra; estratégia para impedir a vulgarização do amor erótico/romântico como móvel das uniões conjugais.

Meu escopo ao vistoriar estas macrotendências da ideologia moral-sexual da cristandade ocidental é ambicioso: referenciá-las à gênese da homofobia tal qual se cristalizou no Brasil desde a época da colo- nização até o presente.

Começo analisando a percepção do perigo representado pela crescente presença da sodomia no mundo eclesiástico medieval e a reação da hierarquia católica visando à erradicação desse perigoso pecado.

Embora os livros penitenciais - que serviam como orientação teológica aos confessores, desde o século VI até o X - contenham sempre, quando menos, um cânone condenatório da sodomia, é São Pedro Damiani (1007-1072) o primeiro autor a dedicar toda uma obra à incriminação da homossexualidade. Trata-se do clássico Liber Gomorrhianus (Livro de Gomorra), datado de 1049, oferecido ao papa Leão IX, onde este escrupuloso sacerdote propõe uma pastoral dirigida aos clérigos a fim de fazê-los abandonar o abominável pecado de sodomia, sugerindo igualmente medidas punitivas contra os relapsos. O motivo que o levou a escrever tal obra é indicado logo no prefácio: “o crescimento deste vergonhoso e abominável vício”, segundo ele, perigosíssimo e hediondo. Seu texto é um dos libelos mais homofóbicos que se escreveu em toda história humana: "A sodomia ultrapassa a sordidez de todos os vícios. É a morte dos corpos, a destruição das almas. Este vício possui a carne, extingue a luz da mente. Expulsa o Espírito Santo do templo do coração humano, introduz o Diabo, que incita à luxúria. Induz ao erro, remove completamente a verdade da mente que foi ludibriada, abre o inferno, fecha a porta do paraíso. Este vício tenta derrubar as paredes da casa celestial e trabalha na restauração das muralhas reconstruídas de Sodoma, pois viola a sobriedade, mata a modéstia, sufoca a castidade e extirpa a irreparável virgindade com a adaga do contágio impuro. Conspurca tudo, desonrando tudo com sua nódoa, poluindo tudo. Não permite nada puro, nada limpo, nada além da imundície" (40).

Diversos historiadores confirmam que, durante boa parte da Idade Média, a sodomia passou a ser popularmente conhecida como vício dos clérigos, de tal modo era cultuada dentro dos conventos, mosteiros, igrejas e cabidos (41). Minhas pesquisas na docu-
37 A. A. Aguiar, Evolução da Pederastia e do Lesbismo na Europa, separata de Arquivo da Universidade de Lisboa, vol. XI, 1926, p. 519

38 "Na noite do Natal, poucas horas antes que nascesse le sus, houve queima geral no mundo todo, como dizem mulos graves doutores da lgreja que Deus fez nos infamados do vício de sodomia. Nosso pai São Boaventura é um dos doutores que isto dizem e, verdade, a razão assim o pe dia, porque como havia de pôr a pureza do céu, lesus Cristo o pé na terra, estando com tão diabólica luxúria contaminada?" IFrei Anselmo de Jesus, Sermão do Auto de Fé lisboa 1621, Biblioteca Nacional de Lisboa, Reservados, 21767-8

39 Josiah Blackmore, e Gregory S. Hutcheson, Queer Iberio: Sexualities, Cultures and Cross ings from the Middle Ages to The Renaissance, London, Duew University Press, 1999

40 São Pedro Damiani, Book of Gomorrah. A Eleventh-Century Treatise against Clerical Homo sexual Practices, Waterloo, Wilfrid Laurier University Press 1982

41 Michael Goodich, The Unmentionable Vice. Homosexuality in the Later Medieval Period Santa Barbara, Ross-Erikson, Publisher, 1979; Jeffrey Richards, Sexo, Desvio e Danação. As Minorias da ldade Média, Rio de Janeiro, Jorge Zahar, 1993, p. 140. 
mentação da Inquisição Portuguesa confirmam essa mesma tendência na Península Ibérica ao longo dos séculos XVI ao XVIII: numa lista de mais de 4 mil denunciados e/ ou confessados constantes nos Repertórios do Nefando, assim como na relação de mais de 400 sodomitas efetivamente presos e processados pelo Santo Ofício, um terço desses indivíduos eram clérigos, sacerdotes e religiosos, valendo, por conseguinte, também para o mundo ibérico a identificação da sodomia como vicium clericorum (42).

Para evitar que os fiéis, ao serem recriminados pelas autoridades eclesiásticas, pela prática de condutas imorais, não repetissem o ditado bíblico, "médico, cura-te a ti mesmo!" (43), urgia que a moralização dos costumes se iniciasse dentro das próprias hostes clericais, daí a importância do Livro de Gomorra como marco dessa campanha contra o relaxamento dos costumes intraclaustros. A forte presença do amor homossexual entre os clérigos colocava em xeque um dos alicerces da moral cristã: a superioridade da castidade e do celibato visà-vis não só a incontinência sexual, como em face dos próprio matrimônio, posto que a Teologia Moral defendia que o estado religioso, com a adoção dos três votos (pobreza, castidade e obediência), representava um estado mais elevado de perfeição do que a opção conjugal. Inúmeros católicos, inclusive colonos do Brasil, foram denunciados e perseguidos pelas diversas inquisições modernas exatamente por defenderem a proposição herética que "é melhor casar do que ser padre” (44). Mais ainda: Pedro Damiani estabelece vinculação direta entre a sodomia, heresia, lepra e o diabo, sendo considerado este pecado mais grave do que o incesto.

A homossexualização do clero representava um enorme risco não só por servir de mau exemplo e estímulo para o relaxamento moral dos leigos, mas também, como bem enfatizava Damiani, a presença de padres homossexuais desacreditava a pureza das relações dos "pais espirituais" com seus "filhos", na medida em que tornava carnal e libidinoso o que devia primar por ser místico e acético. Um clero homossexual coloca em xeque a própria seriedade da vida monástica, por trazer o pecado da sensualidade para dentro das dependências religiosas - o que era muito mais difícil de ser controlado do que as relações com o sexo oposto, posto que as mulheres sempre foram rigidamente impedidas de entrar na clausura (e vice-versa, no tocante aos homens adentrarem-se em instituições femininas).

Se São Pedro Damiani distinguiu-se por sua cruzada contra a sodomia intraclaustros, um outro santo reformador direcionou particularmente sua pregação anti-sodomítica aos libertinos do mundo: o franciscano São Bernardino de Sena (1380-1444).

"Embora o pecado de sodomia fosse tradicionalmente referido como vício inominável, este não é decididamente o caso de Bernardino. Ele o menciona com tal freqüência que foi considerado o mais expressivo e vívido comentarista a respeito da sodomia na Itália na baixa Idade Média... sendo o principal responsável pela exacerbação da grande paúra do Quatrocento italiano, a sodomia, inspirando a primeira perseguição do comportamento homossexual em larga escala na história européia, registrado em Florença e outras cidades italianas. Ao lado do anti-semitismo e a ansiedade da caça às bruxas, a época de São Bernardino é marcada pelo surgimento da intolerância à atividade homogenital, tal qual está documentado na literatura e legislação eclesiástica e civil, podendo-se falar de uma sodomofobia como um fenômeno de intolerância crescente através da Europa, tal qual foi estudada por Boswelle Greenberg"(45).

Bernardino costumava afirmar que Florença era pior do que Sodoma e Gomorra, e que a Toscana tinha mais baixa população do mundo por causa do grande número de amantes do mau pecado - atribuindo a essa abominação a causa da peste que assolou a Itália naquele período (46).

A opinião de São Bernardino de Sena, relativamente ao papel dos amores unis- 
sexuais como causa da diminuição populacional, dá a pista para melhor entender o recrudescimento da homofobia na baixa Idade Média e sua posterior legitimação, no mundo ibero-americano, através dos tribunais da Santa Inquisição. A homossexualidade é apontada como motivadora não só de castigos divinos pretéritos e futuros, representando igualmente deletério risco à recuperação do crescimento habitacional após a dramática depopulação da Europa em decorrência da peste negra. A associação implícita ou explícita do amor unissexual ao risco da bancarrota demográfica tem sido uma constante ao longo da história humana.

Mesmo em nossos dias, quando a humanidade se vê confrontada com o espectro da explosão demográfica, os homossexuais continuam sendo acusados de constituírem uma grave ameaça à sobrevivência de nossa espécie: é comum ouvirmos, entre intelectuais e gente do povo, o argumento de que se for completamente liberado o homoerotismo, a humanidade corre inevitável risco de extinção. Mais do que ledo engano, tal assertiva indica claramente o quanto a sociedade heterossexista teme a normalização dos amores unissexuais, pois suspeita que sua liberação redundaria num crescimento incontrolável de homens e mulheres que deixariam de interagir sexualmente, pondo em xeque a perpetuidade de nossa descendência. Subjacente a este enunciado, está a crença inconfessa de que a maioria dos casais de homens e mulheres continua a praticar o heterossexualismo por mera imposição da moral dominante. Heterossexualidade compulsória e por decreto, portanto...

O já citado dr. Boswell, assim como A. Kinsey e F. Whitam, são unânimes em reconhecer o contrário dessa crença alarmista: "Não há teoria científica contemporânea relativa à etiologia da homossexualidade que defenda que a tolerância social determina sua maior incidência. Mesmo teorias puramente biológicas postulam uniformemente que a homossexualidade seria uma preferência minoritária sob qualquer condição, mesmo nas mais favoráveis”(47).
Whitam, estudando diferentes culturas contemporâneas, chegou à média de $6 \%$ como o total de homossexuais exclusivos, independentemente do maior ou menor grau de tolerância regional (48).

Há provas antropológicas e históricas que confirmam tal assertiva: dois exemplos clássicos remetem-nos às sociedades tribais da Nova Guiné e ao Japão novecentista. Os etoros, papuanos negróides da Oceania, pertencem a uma cultura que poderíamos chamar de homossexualista, de tal forma é oposta à nossa tradição heterossexista abraâmica: todos os rapazes dessa tribo, quando entram na puberdade, são confiados a um jovem adulto, que tem como obrigação transmitir ao adolescente, por via anal, seu próprio sêmen, justificando os nativos que essa é a única forma de tornar aquele jovem iniciando num homem de verdade, futuro transmissor de esperma. Se não receber sêmen pelo ânus, não poderá, quando adulto, fecundar sua futura mulher. Esses povos cumprem à risca um ditado comumente ouvido na Bahia contemporânea: “o baiano dá de pequeno para não dar de grande...", provérbio que eu, paulistano radicado na Boa Terra e cidadão soteropolitano diplomado pela Câmara Municipal, a bem da verdade, atesto ser pura maledicência...

Tão homossexualista é a cultura etoro, assim como a de diversas outras sociedades da Oceania, que a cópula heterossexual é proibida de 205 a 260 dias por ano, estando limitada a certos espaços marginais à aldeia, rodeada de uma série de restrições heterofóbicas.

Pois bem: mesmo nessa sociedade radicalmente homossexualista, estudos revelam que a taxa anual de fecundidade da população se reduz em apenas $15 \%$, se comparada com os demais povos heterossexistas, não chegando portanto essa prática privilegiada do homoerotismo a ameaçar a perpetuidade desses exóticos exemplares da espécie humana (49).

Um outro exemplo histórico que contradiz a fobia irracional de que a liberação homossexual possa provocar o fim de nossos semelhantes remete-nos ao Japão antes
47 Boswell, op.cit., pp. 8-9.

48 Frederick Whitam, Male Homosexuality in Four Societies, New York, Praeger, 1986

49 Dennis Werner, op. cit., pp. 345-62 
50 Ihara Saikaku, The GreatMirro of Male Love, Stanford Stanford University Press, 1990

51 Luiz Mott, "Antropologia, População e Sexualidade", in Re vista Gente, Departamento de Antropologia da UFBa, ne 1 , jul.-dez./1984, pp. 87-103

52J. Richards, op. cit., p. 150

53 Donald J. Kagay and Theresa M. Vann, "Peste Negra: The Fourteenth-Century Plague Epidemics in Iberia", in On the Social Origins of Medieval Institutions, Leiden, E. J. Brill, 1998 , pp. 47-62 da restauração da dinastia Meiji (1865), quando a prática homossexual era socialmente aceita como comportamento normal e moralmente correto. Hoje se sabe que grande parte dos valorosos samurais e a maior parte dos delicados atores transformistas do teatro nô e kabuki eram praticantes do homoerotismo, gozando de enorme admiração e aplauso geral (50). Pois bem: comprova a demografia histórica que, apesar da grande tolerância e prática generalizada da homossexualidade, a população nipônica cresceu naquele período até os limites extremos da subsistência física, derrubando-se assim as ilações alarmistas de que a liberação do amor entre parceiros(as) do mesmo sexo levaria necessariamente à depopulação e extermínio do Homo sapiens (51).

Apesar de há décadas ser este o ensinamento de diferentes ramos do saber, persiste no imaginário coletivo esta conclusão simplista: já que os homossexuais não reproduzem - "bicha com bicha dá lagartixa", "mulher com mulher dá jacaré”, ou ainda, "homem com homem dá lobisomem" -, gays e lésbicas representam séria ameaça à sobrevivência humana.

Esta é uma das explicações da recrudescência da homofobia logo após a enorme mortandade registrada na Europa em conseqüência da peste negra: “os homossexuais se tornaram bodes expiatórios para a peste e para o declínio populacional, e eram claramente vistos como um ultraje para o código de respeitabilidade burguesa, recém-estabelecido e influenciado pelas Ordens Mendicantes". Como se sabe, aproximadamente $40 \%$ da população européia pereceu em consequiência da peste negra (1348), provocando enorme desequilíbrio sociodemográfico, inclusive em Portugal, daí a necessidade premente de repopular vastos territórios desertificados de gente após tamanha mortandade. Além de "os pregadores invariavelmente atribuírem o início da Peste Negra à sodomia" (52), o desperdício do sêmen por parte dos sodomitas passou a ser ainda mais atentatório dada a calamidade populacional vivida numa quadra tão dramática (53).
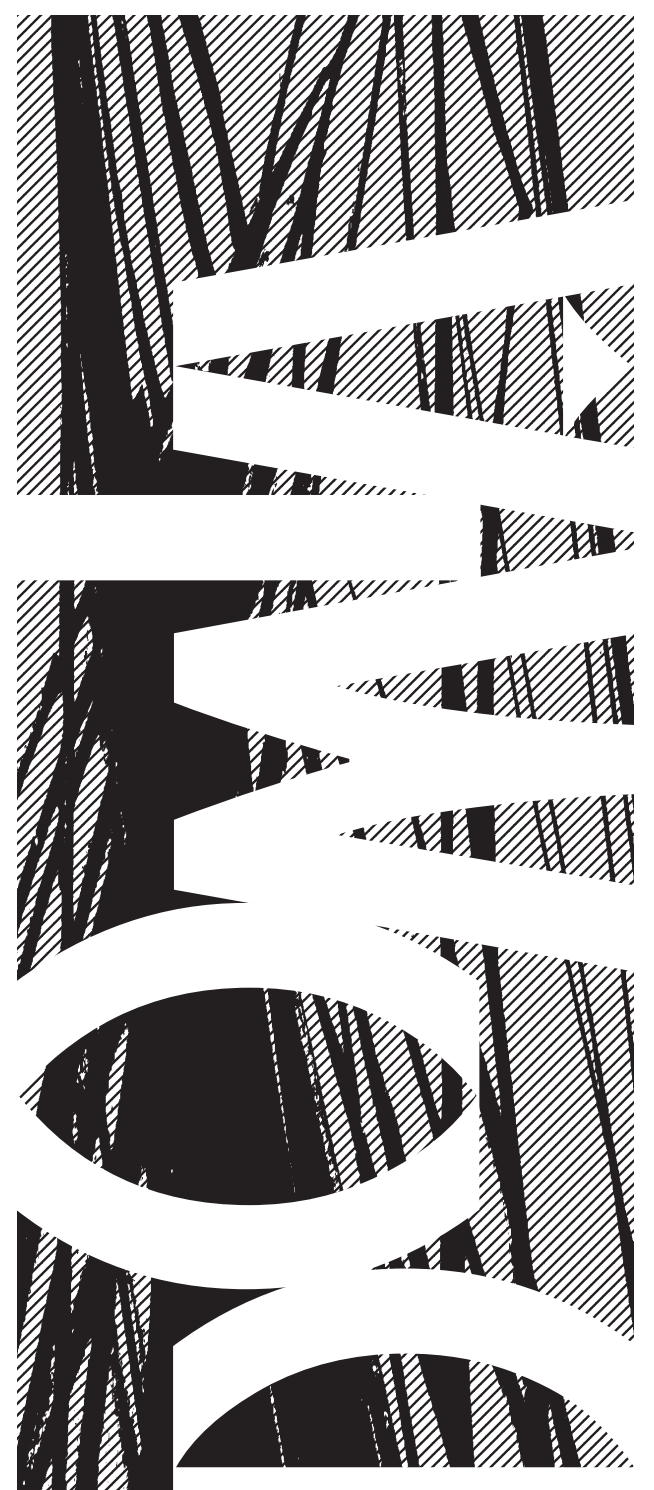

西

\section{(1)}

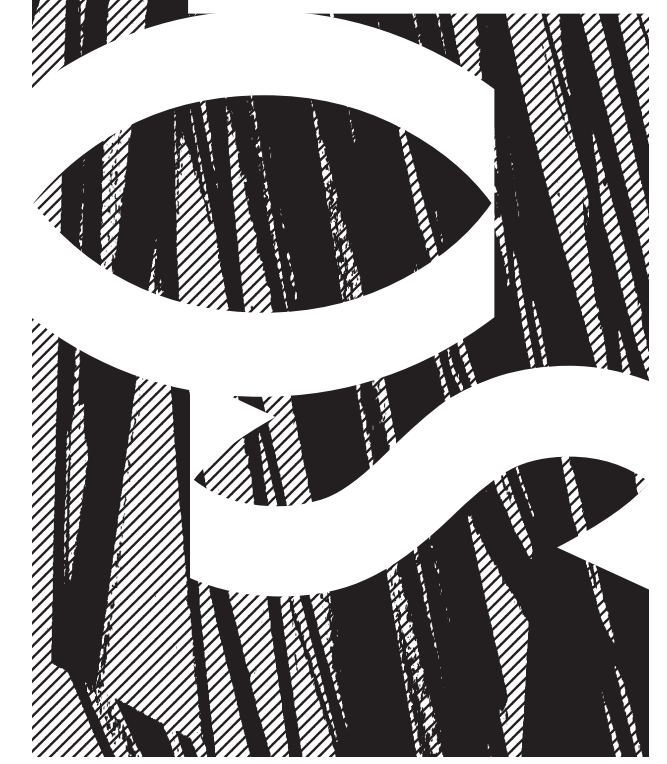


Se de um lado a imoralidade do clero e o espectro da peste desencadearam reações de intolerância localizadas ou regionais contra os sodomitas, uma terceira hipótese explica a generalizada onda de desconfiança e repressão aos amores unissexuais onde novamente se revela o temor de seu caráter intrinsecamente revolucionário e demolidor: a preservação do padrão tradicional do casamento heterossexual e da constituição da família burguesa. Os gays foram vistos, e de fato assim agiram, em variegados contextos históricos, como perigosos "filhos da dissidência".

Segundo relatam os etnógrafos, a quase totalidade das sociedades humanas teve como critério definidor dos enlaces matrimoniais, não o amor romântico ou paixão sexual, mas os interesses patrimoniais de aliança das famílias dos nubentes. Matrimônio = Patrimônio. Ainda no tempo de nossos avós ou bisavós, sobretudo nas classes mais abastadas e controladas pela moral cristã, predominavam os casamentos arranjados, onde o que menos importava era a vontade dos noivos. Na esteira da tradição judaica, ao longo de toda a Idade Média, os cristãos continuam a visualizar a mesma finalidade no casamento: antídoto contra a tentação sexual e a geração de numerosa prole. Casa-se para procriar, de preferência filhos homens. Filhos numerosos são interpretados como inefável bênção divina e felicidade suprema. A esterilidade da mulher representa desgraça máxima, castigo de Deus. O apóstolo Paulo e Jesus reinterpretam neste particular a Lei de Moisés, passando o cristianismo a condenar o divórcio (54), embora somente a partir do século XIII a Igreja confira ao casamento o status de sacramento, ao lado do batismo e da ordem (55).

Teólogos, como o bispo Huguccioe Jean Gerson, defendiam, ainda no século XV, que mesmo dentro do matrimônio o sexo, até na posição "papai-mamãe", também conhecida como "posição do missionário", constituía pecado venial (56). Predominava, em amplos círculos da cristandade, o vetusto ensinamento de São Jerônimo: “Um homem sábio deve amar sua mulher com discernimento e não com paixão e, conseqüentemente, controlar seus desejos e não se deixar levar à copulação. Nada é mais imundo do que amar a sua mulher como uma amante" (57).

Dentro desse estóico código moral, o amor deve suceder ao casamento e não necessariamente precedê-lo, obrigando a Santa Igreja a se dar publicidade da cerimônia nupcial como forma de controlar os desejos, interferir nas alianças familiares, exigindo para tanto que os proclamas fossem realizados com bastante antecedência, evitando-se assim os riscos da fraude e sobretudo o pecado e crime da bigamia. A burocratização cartorial do matrimônio, formalizada a partir de então, além de garantir muitas benesses e polpudas espórtulas ao clero, visava o controle integral, através dos sacramentos, de todo o ciclo vital do rebanho dos fiéis: batismo no nascimento, matrimônio na maturidade sexual, extrema-unção na hora da morte (58).

Uma perigosa brecha persistia, porém, embutida na tradição cristã: segundo o direito canônico medieval, os próprios nubentes eram reconhecidos como os legítimos ministros do matrimônio, bastando para sua validação legal que o casal declarasse perante uma testemunha, podendo ser inclusive um leigo, que a partir daquele instante passavam ambos a reconhecer-se e coabitar como marido e mulher. Tal possibilidade canonicamente válida colocava em grave risco o controle da família cristã, desde quando sobretudo os jovens, "tentados pelo demônio", realizavam clandestinamente o chamado "casamento de palavras", arruinando os projetos de aliança familiar zelosamente construídos pelos progenitores.

Foi somente o Concílio de Trento (15451563) que proibiu rigorosamente tal prática, obrigando a divulgação dos banhos corridos e a presença de um sacerdote oficiante como condição sine qua non da validade desse sacramento, ratificando-se nesse mesmo sínodo tridentino outro dogma relativo à união conjugal católica: a stabilitas - a estabilidade indissolúvel dos casados.
54 Serafin Sudejo, Diccionario de la Biblia, Barcelona, Editoria Herder, 1964.

55 P. Ariès e A. Béjin (eds.), Sexua lidades Ocidentais, São Paulo, Brasiliense, 1985, p. 160 ("O Amor no Casamento").

56 Richards, op. cit., p. 40.

57 São Jerônimo, Contra Joviniano, I, 49, apud P. Ariès, op cit., p. 157.

58 Georges Duby, Amor e Sexua lidade no Ocidente, Lisboa, Terramar, 1991. 
"Equilíbrios tão cuidadosamente preparados e tão frágeis, onde se patenteia o caráter coercitivo da aliança entre famílias e dos intercâmbios de rapazes e moças, teriam sido comprometidos se os casamentos pudessem ser rompidos com demasiada facilidade, e as esposas repudiadas... Temse a impressão de que a stabilitas do casamento precoce era a condição da stabilitas da comunidade inteira. Cabia à própria comunidade fazer com que ela fosse respeitada"(59).

Nesse contexto de crescente domesticação das moralidades, como agiam e eram vistos os praticantes do amor unissexual, ou melhor, do abominável e nefando pecado de sodomia? Com a palavra nosso já conhecido São Bernardino de Sena:

"Pode existir um jovem rapaz de raros talentos, alguém de grande inteligência, feito para realizar maravilhas, mas uma vez corrompido pela sodomia, ele se transforma numa criatura do Diabo. Ele rejeita todas as coisas naturalmente boas, todos os pensamentos de Deus, do Estado, de sua família, rejeita seus negócios, sua honra, sua própria alma. Ele só pensa em assuntos malignos" (60).

Quem melhor sintetizou em nossa língua a suposta malignidade revolucionária representada pelos sodomitas foi o cardeal D. Henrique (1512-80), segundo inquisidor geral da Inquisição Portuguesa, que, em 1574, obteve um Breve de Gregório XIII

59 Ariès, op. cit., p. 178.

60 Richards, op. cit., p. 150.

61 Colectório de Bulas e Breves Apostólicos, Biblioteca Nacional de Lisboa, Seção de Reservados, Códice 105 A, fls. 75 77

62 Tribunale Perfectum sive Comentaria ad Regimen Sancti Offici Regni Portugaliae, Manuscritos da Livraria, Arquivo Nacional da Torre do Tombo, n. 1358 1359, Joannis Alvares Soares, Tomo I, Gloss. 38

63 Frei Felipe Moreira, Cônego de Santo Agostinho, Sermão do Auto de Fé, Lisboa, 25-6-1645, Biblioteca Nacional de Lisboa Reservado 3243, P. ratificando a pena de morte aos sodomitas, referidos na documentação inquisitorial como "filhos da dissidência" (61). Dissidência, cisma, cisão equivale a se separar de uma corporação por divergência de opiniões, atentar contra a tão desejada unidade do orbe católico, “um só rebanho e um só pastor!". Os sodomitas atentavam contra esse desiderato ideológico, assustando todas as camadas sociais, dos donos do poder ao populacho. Tanto quanto ou até mais que os hereges, os filhos da dissidência, devido ao seu inconformismo numa questão reputada como indiscutível $-a$ moral sexual natural-, ultrajavam com sua dissidência erótica o ensinamento oficial da ortodoxia, ostentando o caráter revolucionário de sua insubordinação às leis divinas e insistência na prática do peccatum contra naturam.

Eis o pensamento oficial da Inquisição Portuguesa sobre este particular:

“O crime de sodomia é gravíssimo e de tal qualidade que houve quem afirmasse com grande fundamento que quem o cometia era suspeito na fé, e tão contagioso, que mostra a experiência pois em breve tempo infecciona não só as casas, lugares, vilas e cidades, mas ainda Reinos inteiros, e é obrigação precisa atalhar males grandes e de que Deus tanto se ofende, com meios eficacíssimos e, para os descobrir, não há outro meio mais adequado que a denúncia forçada"(62).

Num sermão num auto-de-fé, realizado em Lisboa em 1645, onde foram queimados diversos sodomitas, esse mesmo pensar é assim ratificado: "Sodoma quer dizer traição. Gomorra, rebelião. É tão contagiosa e perigosa a peste da sodomia, que haver nela compaixão, é delito. Fogo e todo rigor, sem compaixão nem misericórdia! Tanta força tem o lugar apestado deste vício que para livrar dele até a um inocente, é necessário violência de muitos anjos" (63).

Considero um precioso achado sociolingüístico a caracterização dos amantes do mesmo sexo como "filhos da dissidência", pois, por mais alienado, enrustido e prépolítico que seja um homossexual, sua insubordinação aos cânones da moral oficial representa uma violenta revolução que ameaça arruinar os alicerces constitutivos da hegemonia do macho e da sociedade heterossexista. Ao tomar como móvel da aproximação dos corpos tão-somente a paixão erótica e eventualmente o amor romântico, os gays, desde priscas eras, privilegiaram a emoção e o prazer em detrimento da reprodução biológica ou das alianças patrimoniais. Anteciparam em milênios o que Freud antevia como elemento desesta- 
bilizador da hierarquia dos sexos em nossa civilização: a possibilidade de libertar os amantes de uma gravidez indesejável numa sociedade que desconhecia métodos eficazes de anticoncepção. Foram os homossexuais os apóstolos do sexo livre, descomprometido do espectro da gravidez indesejada, dissidentes da dominante endogamia de classe e raça (64).

Uma segunda e não menos assustadora ameaça dos filhos da dissidência nestes quatro mil anos de história pós-abraâmica tem sido o questionamento da cruel hegemonia falocrática do macho todo-poderoso, da perpetuação da hierarquia patriarcal através de contratos nupciais, onde a cobiça do patrimônio prevalece no matrimônio, onde o prazer sexual e emocional é relegado à periferia da instituição conjugal. Os homossexuais, inversamente, ao privilegiarem desde sempre a atracão física, a emoção, o amor e paixão, como ingredientes indispensáveis dos arranjos íntimos interpessoais, tornaram-se, historicamente, se não os inventores, quando menos os precursores e principais praticantes do amor romântico, isto, muitíssimos séculos antes da paixão impossível de Romeu e Julieta e dos trovadores medievais.

Tal dissidência inovadora ao modelo erótico-sentimental dominante foi altamente reprimida por ser causadora de incontrolável desestabilização da autoridade do pater-familias e da família patriarcal, tanto que o casamento de palavras passou a ser perseguido como grave delito do conhecimento da justiça eclesiástica, posto representar uma forma também revolucionária e insurgente de os jovens contestarem o autoritarismo familiar.

A repressão anti-homossexual tem a ver diretamente com o medo representado pelo cisma, quase heresia, representada pelo estilo de vida dos sodomitas, onde estão reunidos ingredientes explosivos, tais como a democracia sexual, o questionamento da hierarquia dos gêneros, a alternativa da unissexualidade, a inversão dos papéis sexuais, o travestismo, a transexualidade, todos comportamentos e condutas altamente desestabilizadores da sociedade heteros- sexista e falocrática, onde as regras de comportamento de gênero e o erotismo são definidos hierarquicamente garantindo a supremacia do macho. As uniões nômades ou passageiras, a "promiscuidade", a rotatividade de parceiros e inversão de performances, a androginia são mais alguns elementos revolucionários da subcultura gay, já documentada no mundo lusobrasileiro desde o século XVI, constantes ainda hoje em dia (65), que questionam e assustam a sacralidade e indissolubilidade dos vínculos matrimonias dos casais heterossexuais. Daí a repulsa neurótica de alguns homófobos mais autoritários que se opõem tenazmente à legalização da parceria civil e mais ainda, ao casamento gay, alegando que a família e o matrimônio heterossexual estariam gravemente ameaçados. Novamente aqui, a mesma fobia mitológica, de que a liberação homossexual redundaria na bancarrota da heterossexualidade. Freud explica...

\section{SODOMA TROPICAL}

Após ter discutido a gênese do preconceito anti-homossexual na tradição abraâmica e mostrado que no imaginário de nossos antepassados da Antiguiidade, durante boa parte da Idade Média e particularmente na Península Ibérica a partir da Idade Moderna, o amor entre pessoas do mesmo sexo foi violentamente reprimido devido a seu caráter eminentemente revolucionário e desestabilizador de significativos princípios e regras sociais considerados basilares para nossos ancestrais, concluo este passeio pelos alicerces, ruínas e fantasmas de Sodoma, mostrando como a fobia à homossexualidade na sociedade brasileira contemporânea tem relação direta com o projeto civilizatório do macho português no contexto escravista do Novo Mundo. Novamente aqui, é a etno-história que nos fornece a melhor pista para desvendar o background ideológico da homofobia contemporânea.

Ao desembarcarem na Terra dos Papa-
64 Daniel Guerin, A Revolução Ho mossexual, São Paulo, Brasilien se, 1980; Guy Hocquenghem A Contestação Homossexua São Paulo, Brasiliense, 1980

65 Luiz Mott, A Cena Gay de Salvador em Tempos de Aids, Salvador, Editora Grupo Gay da Bahia, 2000. 
gaios os colonizadores traziam arraigados em suas consciências forte sentimento antihomossexual, registrando-se alguns casos de sodomitas que foram ameaçados de ser jogados no mar, ou gravemente agredidos, durante as viagens transoceânicas, acusados de serem eles os causadores da ira divina, manifesta através das calmarias, tempestades ou epidemias ocorridas durante a viagem. Mitos homossexuais povoavam o imaginário de nossos colonos: já em 1594, malgrado o mandamento paulino de que "estas coisas não sejam sequer mencionadas entre vós”, as pessoas não resistiam à tentação de conversar e até citar "causos" tendo o amor italiano como mote. Eis um exemplo: Estêvão Cordeiro, 31 anos, lavrador residente no Engenho Carnijo, na freguesia de Santo Amaro, em Pernambuco, confessou perante o Inquisidor que, "estando em prática com alguns vizinhos, não se lembra em que tempo nem a que propósito, disse que em Roma andavam as mulheres com os peitos descobertos e que os Padres Santos concediam indulgências aos homens que com elas dormissem carnalmente, por respeito de com isso divertir aos homens de fazer o pecado nefando..." (66). A fama de que a Itália e Roma em particular eram sucursais de Sodoma e Gomorra impregna o imaginário luso-brasileiro ao longo de toda a história moderna.

Após séculos e séculos de condenação e repressão ao "mau pecado" eis que os reinóis confrontam-se de repente, na Terra Brasilis, com povos que além de viverem nus, sem nenhum pejo ou vergonha, ostentavam práticas sexuais completamente antagônicas à moral cristã, incluindo incesto, poligamia e outras “perversões", então rotuladas de "invenções diabólicas”, sobretudo a generalizada prática do abominável e nefando pecado de sodomia. Diz um cronista na Bahia em 1587:

“Os Tupinambá, não contentes em andarem tão encarniçados na luxúria naturalmente cometida, são muito afeiçoados ao pecado nefando, entre os quais se não tem por afronta. E o que se serve de macho se tem por valente e contam esta bestalidade por proeza. E nas suas aldeias pelo sertão há alguns que têm tenda pública a quantos os querem como mulheres públicas" (67).

Assim, o primeiro perigo a ser evitado pelos colonizadores era o risco do "contágio" pelo mau pecado. Temor e risco ampliado com a chegada dos primeiros escravos da Guiné, posto que, também na África, documentação fidedigna atesta que o "vício dos bugres" era igualmente conhecido, praticado e, em certas etnias, socialmente aceito e até divinizado. Não é por menos que o primeiro travesti documentado na história pátria é um negro, Francisco Manicongo, membro de uma seita de temidos feiticeiros homossexuais de tradição banto (68).

Acresce-se um outro fator à temida homossexualização da América Portuguesa: o próprio perfil heterodoxo dos primeiros povoadores da novel colônia. Já em 1549 desembarca em Pernambuco, na época ainda chamada de Nova Lusitânia, o primeiro sodomita degredado pela Inquisição: Estêvão Redondo, criado do governador de Lisboa, tendo seu nome assentado no $\mathrm{Li}$ vro dos Degredados com o selo do próprio governador local (69). Seguindo a este, nas décadas subseqüentes, diversos outros degredados sodomitas, jovens e adultos, estabelecem-se sobretudo nas capitanias do Nordeste, todos inculpados no "vício nefando", alguns, considerados pelos inquisidores como "incorrigíveis". A imensidão do território e sua ocupação rarefeita, o afrouxamento da moral e relaxamento do clero são alguns dos fatores que tornavam nossa terra um paraíso para quantos quisessem se entregar aos amores proibidos.

Portanto, preocupados em evitar que a Terra de Santa Cruz se tornasse uma reedição tropicalista de Sodoma e Gomorra, El Rei delibera cortar a cabeça da hidra sodômica em seu nascedouro: no próprio regimento de instalação das capitanias hereditárias (1532), confere-se aos capitãesmores autoridade para condenar à morte, sem necessidade de autorização da metró- 


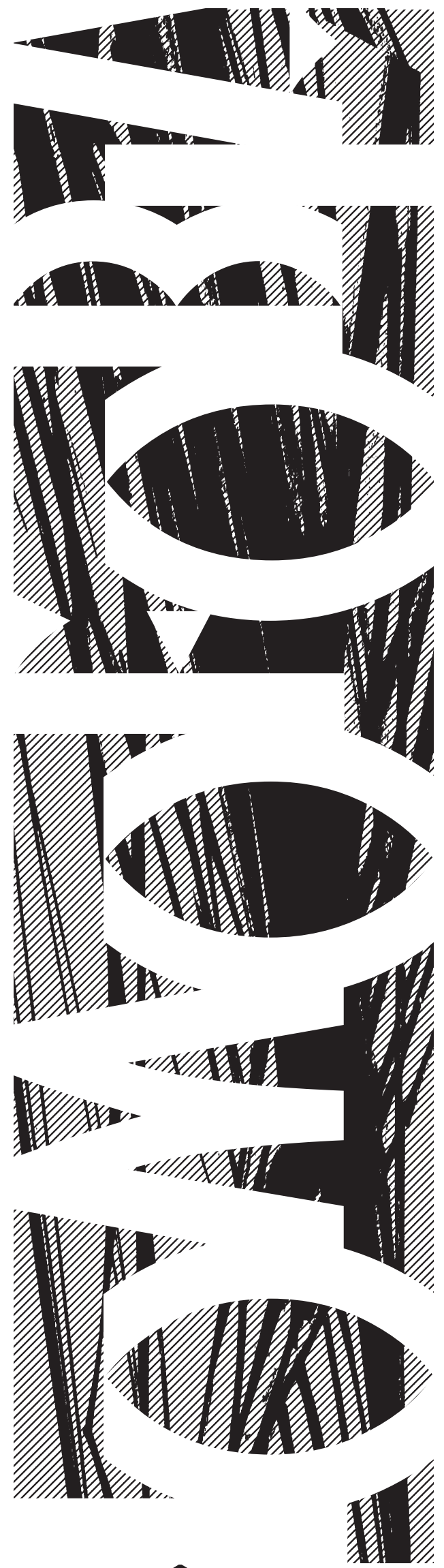

pole, apenas os culpados em quatro gravíssimos crimes: traição e aliança com os índios e invasores; heresia; fabricação de moeda falsa; e a prática da sodomia. Pena capital aos traidores e trânsfugas, porque ameaçavam a soberania e posse da terra; aos hereges, por desafiarem a unicidade da Santa Madre Igreja; aos falsificadores de moeda, por desestabilizarem a vida econômica; aos sodomitas, não só pelo risco de atraírem a maldição divina, mas também por revolucionarem os costumes, sobretudo os alicerces da família, da moral e da própria estrutura da sociedade.

No Novo Mundo, nesse início da era moderna, a homossexualidade é muito mais temida do que na Europa, na medida em que a frágil conjuntura colonial vai exigir um incremento da autoridade do macho, significativo crescimento demográfico e reforço das funções sociais da família patriarcal. São várias as aproximações que podemos fazer entre o desenvolvimento ideológico da homofobia nos primórdios da colonização da América Portuguesa e sua gênese histórica no mundo abraâmico. A primeira analogia tem a ver com o projeto demográfico pró-natalista de nossos primeiros povoadores: urgia que a imensidão dos Brasis fosse ocupada e possuída pelos portugueses, caso contrário, outros aventureiros lançariam mão deste éden tropical.

Na capitania de Pernambuco, na mesma Visitação do Santo Ofício de 1594, um carpinteiro lusitano, Pero Gonçalves, dizia sem pejo: "Fornicar, fornicar que farte, que del Rei é a terra e que nunca ninguém foi ao inferno por fornicar [em lugar da palavra fornicar, que aqui se escreveu, disse a palavra portuguesa que isso significa, desonesta, (foder), que por honestidade se não escreveu]" diz o notário da Visitação (70). Certamente esse destemperado reinol estava imbuído da idéia que "ultra equinotialem non pecari" - abaixo do Equador não há pecado! Daí a conhecida sugestão ultraliberal do padre Nóbrega, que de Portugal se enviassem mulheres para casar com os brancos - não importando que fossem mulheres perdidas, pois aqui achariam quem as quisesse desposar e com seus fi-
70 Confissões e Denunciacões de Pernambuco, 1593-1595, op cit., p. 436 . 
lhos povoar o litoral e os sertões deste Novo Mundo. Ora, sodomitas não reproduzem, cometem o pecado mortal de desperdiçarem a semente da vida, daí sua repulsa numa terra carente de novos colonos.

Igualmente como sucedeu nos primórdios da formação dos povos descendentes de Abrãao, também aqui nossos ancestrais tiveram de enfrentar dramático impasse: uma minoria demográfica - os brancos colonizadores - confrontou-se com uma imensidão de colonizados - índios, negros, mestiços, escravos em sua maioria -, que só foram subjugados à exploração e tirania dos donos do poder mediante o emprego da violência máxima, monopólio dos machos brancos. Numa sociedade em que, generalizadamente, os descendentes dos europeus representavam no máximo $25 \%$ da população, se excluirmos desse contingente as mulheres, os idosos e as crianças, restarão aproximadamente $10 \%$ de homens brancos, responsáveis pela manutenção da ordem e subserviência da multidão de todos os demais oprimidos.

Somente homens fortes, ultraviolentos, poderosos, conseguiram a proeza de manter sua hegemonia em face de $90 \%$ da população carente deste diferencial privilégio: ser macho branco. Daí o machismo latino-americano apresentar-se muito mais virulento e institucionalizado do que o observado na Península Ibérica, pois, nas regiões plurirraciais dominadas pelo modo de produção escravista, ser super-homem foi condição sine qua non da manutenção do próprio projeto colonial (71). Um homem delicado, medroso, efeminado, sensível, jamais conseguiria manter o indispensável clima de terror para conservar submissa a "gentalha", todos os que não eram machos brancos. Daí a repressão bru-

71 LuizMott, "Sexualidade no Brosil Colonial", in Carlos A. M. Sá (org.), Sexualidade Huma na, Rio de Janeiro, Revinter, 2000 , p. $117-29$

72 Hocquenghem, op. cit., p. 16 E. Blackwood (ed.), The Many Faces of Homosexuality, New York, Harrington Park Press, 1986; J. A. McCaffreey led.) The Homosexual Dialectic Englewood Cliffs, Prentice Hal Inc., 1972. das nas relações heterossexuais. "A ruptura com os amores interclassistas é a condição de salvação homossexual", lembra um dos fundadores do movimento gay da França, o já citado Hocquenghem (72). Numa colônia com enorme contingente de índios e negros, cujas culturas demonstravam grande tolerância à libido unissexual, nada mais ameaçador do que a aliança sexual e afetiva entre sodomitas brancos com membros de outras raças, posto que tais aproximações íntimas minavam a desejada distância entre opressores e oprimidos. Dar carinho, prazer e eventualmente até dar as costas e deixar-se penetrar por machos negros ou índios, a quem as regras consuetudinárias determinavam que fossem tratados na "porrada", revolucionava perigosamente os códigos de interação estamental, dando ousadia aos oprimidos e estímulo a se rebelarem contra a dominação dos que detinham o controle legal do uso da espada, do chicote e das armas de fogo.

Também no Novo Mundo, como sucedeu na Idade Média, o amor homossexual foi duramente reprimido por constituir deletéria ameaça à estabilidade da família tradicional, na medida em que minava perigosamente a autoridade patriarcal no tocante ao controle das estratégias de aproximação dos sexos e a constituição de novas unidades familiares. Na América Portuguesa, assim como na Espanhola, a endogamia das famílias de origem européia foi a estratégia oficial, abençoada pela Igreja, instaurada a fim de evitar que "cristãos-novos" e "gente de sangue impuro" se unissem e infectassem as "famílias limpas". A endogamia da oligarquia colonial, evitando a mistura de seus descendentes com a raia miúda e sobretudo com a gentalha não-branca, tornou-se uma obsessão das elites fundiárias, optando muitas famílias, às vezes, pelo enclausuramento forçado de suas filhas donzelas, evitando assim uniões com indivíduos considerados de condição social ou racial inferior. Os famigerados processos de "qualificação de pureza de sangue", indispensáveis para admissão na clericatura e nas altas funções governamentais, visavam exatamente manter na elite tão-somente os cristãos-velhos. 
A união livre dos homossexuais, desrespeitando as barreiras de raça, estamento e idade, parceria baseada tão-somente na paixão e mútua empatia, detonava a ordem familista patriarcal tradicional, daí o afinco com que os donos do poder colonial reprimiram os "filhos da dissidência".

Hoje em dia, nos inícios do terceiro milênio, quando muitos e muitos machistas homófobos repetem acriticamente a terrível pena de morte: "Viado tem mais é que morrer!", e quando, na prática, os homossexuais continuam sendo, no Brasil, dentre todas as minorias sociais, as principais vítimas do preconceito e discriminação, estamos presenciando a persistência de um mito, velho de quatro mil anos, imposto a nossos antepassados à custa de pedradas e da fogueira da Inquisição - mito cruel e pernicioso que hoje, na era dos computadores, urge que ceda lugar ao respeito dos direitos humanos e à diversidade cultural. Sobretudo, porque há muito tornou-se ridiculamente caduca aquela fobia irracional ao potencial revolucionário representado pelo amantes do mesmo sexo. O problema atual da humanidade é a explosão demográfica, sendo portanto absurdo e antiecológico pretender aumentar a população "como as estrelas do céu e as areias do mar". Hoje gays e lésbicas deveriam ser premiados por colaborarem efetivamente com o controle da natalidade (73).

Uma segunda invenção dos homossexuais, antigamente revolucionária e temida, tornou-se hodiernamente inofensiva: o sexo prazer dissociado da reprodução e o primado do amor romântico como critério das uniões conjugais. Hoje, graças à pílula, ao preservativo e aos novos métodos anticoncepcionais ou abortivos, os heterossexuais também podem manter relações sexuais sem o risco da gravidez indesejada, apanágio dos sodomitas em épocas coevas (74). Da mesma forma, o amor romântico e a atração física, antigamente privilégio dosfilhos da dissidência, tornaram-se hoje, graças aos efeitos da globalização da cultura ocidental, a regra áurea da aproximação dos sexos em grande parte do universo. E o que falar da moda unissex, dos homens com brinco na orelha, das mulheres usando jeans, da cultura "GLS", das drag-queens, das operações transexuais...

Parece que uma parcela dos próprios homossexuais, depois que saíram do armário, nos anos pioneiros da Revolução de Stonewall (1969), o festejado coming out (75), tende hoje mais à integração do que à dissidência: “Os gays organizados representam hoje uma forma nova de encarar a vida. Casam, adotam crianças. Os gays não querem mais revolucionar o mundo. A revolução sexual ocorreu na década de 70 e já é fato consumado. Agora é a hora da estabilidade, é a hora de se impor, de conquistar lugares. Estamos fazendo isso" (76).

Estas são as palavras do primeiro gay assumido, do partido republicano, a fazer parte oficial do atual governo norte-americano. Homossexuais que conquistam lugares e se impõem não deixam de representar uma força revolucionária no mundo heterossexista. Enquanto isto, na Terra dos Papagaios, deputados crentes se unem à TFP e à CNBB, advertindo a população e os parlamentares que não aprovem o projeto de lei que regulamenta a parceria civil registrada entre homossexuais, pois o "casamento gay" além de levar à destruição da família brasileira, redundará em incalculáveis castigos divinos contra nossa pátria.

Não é por menos que o arcebispo de Florianópolis não teve pejo em declarar: “Os gays são gente pela metade. Se é que são gente!" (77).
73 David Fernbach, The Spiral Path: a Gay Contribution to Human Survival, Boston, Alyson Publications, 1981

74 Lawrence Lippton, A Revolução Erótica, São Paulo, Ibrasa 1975; Vance Packard, A Re volução Sexual, Rio de Janeiro, Record, 1982

75 Sue March, Libertação Homos sexual, São Paulo, Nova Épo ca, 1981: Michael Warner, "Fear of a Queer Planet", in Social Text, volume 9, n. 4 1991, pp. 3-17; Danie Guerin, A Revolução Sexual São Paulo, Brasiliense, 1980 76 Veja, 16/4/2001. 77 A Notícia (SC), 1/10/1998. 